\title{
HUBUNGAN ASUPAN ENERGI DAN GIZI MAKRO SERTA STATUS GIZI PADA PASIEN PRE- EKLAMSI DI RSIA SITI FATIMAH KOTA MAKASSAR
}

\author{
Rudy Hartono', Hikmawati Mas'ud ${ }^{2}$, Andi Syam Haeru ${ }^{3}$ \\ 1 Jurusan Gizi, Politeknik Kesehatan Kemenkes, Makassar \\ 2 Dinas Kesehatan, Kabupaten Gowa
}

\begin{abstract}
ABSTRACK
Preeclampsia until now is still a health problem that can not be solved completely. Statistical data in developed countries shows that $10-30 \%$ of all maternal deaths are caused by preeclampsia. Preeclampsia is one of the three major causes of maternal death in addition to bleeding and infection. Nutritional intake is an indicator to see the nutritional adequacy and upper arm circumference of pregnant women is one tool to assess the nutritional status, so it can be known complications during pregnancy. This study aims to determine how the relationship of energy intake and macro nutrition and nutritional status with the incidence of preeklamsi in RSIA Siti Fatimah Makassar. The type of this research is cross sectional study. Data collection was done by interview using questionnaire with total sample as many as 34 people. The result of the research using statistical analysis of chi-square test showed that energy intake, protein intake, fat intake, and carbohydrate intake as well as nutritional status were obtained by $p$ values, $p=0.584, p=0.611, p=0.416, p=0.649$ And $p=0.547$ means that there is no relationship between energy intake and macro nutrition and nutritional status in patients preeklamsi in RSIA Siti Fatimah Makassar. It is expected that the respondent health officer can increase the frequency of counseling both personally and group related factors that can influence the occurrence of preeclampsia.
\end{abstract}

Keywords

: Intake of Energy, Macro Nutrition, Nutrition Status, Preeclampsy

\section{PENDAHULUAN}

Seluruh negara di dunia memberi perhatian yang cukup besar terhadap Angka Kematian lbu (AKI), sehingga menempatkannya diantara delapan tujuan Millennium Development Goals(MDGs) yang harus dicapai sebelum tahun 2015.Komitmen yang ditandatangani 189 negara pada September 2000 itu, pada prinsipnya bertujuan untuk meningkatkan taraf hidup dan kesejahteraan manusia (Yustina, 2007).

$$
\text { Menurut data World Health }
$$

Organization (WHO) tahun 2014, sekitar 800 perempuan meninggal setiap harinya akibat komplikasi kehamilan dan proses kelahiran. Sekitar 99\% dari seluruh kematian ibu terjadi di negara berkembang.Sekitar $80 \%$ kematian maternal merupakan akibat meningkatnya komplikasi selama kehamilan, persalinan dan setelah persalinan.Sedangkan di Indonesia, sekitar 18.000 wanita meninggal setiap tahunnya akibat komplikasi kehamilan dan persalinan (Rohfiin, 2016)

Pre eklampsia adalah sindrom yang terdiri dari tingginya tekanan darah (hipertensi), tingginya kadar protein dalam urin (hemaproteuria), dan banyaknya cairan yang ditahan oleh tubuh sehingga tungkai kaki ibu hamil menjadi bengkak. Dahulu, pre eklampsia disebut toksemia atau gejala keracunan pada ibu hamil. Pre eklampsia umumnya terjadi pada penderita hipertensi. Hamil pertama kali mempunyai risiko pre eklampsia yang lebih besar dengan persentase 5-10\% kehamilan (Rohfiin, 2016 ).

Angka Kematian lbu (AKI) di dunia pada tahun 1990 adalah 400 per 100.000 kelahiran hidup, turun menjadi 260 pada tahun
2008. Angka tertinggi terdapat di Afrika Sub Sahara (64,0\%), diikuti Asia Selatan (29,0\%), dibandingkan dengan Amerika Latin dan Karibia (85\%), Amerika Utara (23\%) dan di Eropa (10\%). Di Asia Tenggara AKI yang tertinggi adalah Republik Rakyat Demokratik Laos $(58,0 \%)$, Timor Leste $(37,0 \%)$ dan Kamboja $(29,0 \%)$, dan negara yang kematian ibu relative rendah yaitu Malaysia (31\%), Brunei Darussalam (21\%) dan (9\%) Singapura (Childinfo, 2012).

Berdasarkan data yang diperoleh dari World Health Organiationmenyatakan bahwa kasus kematian ibu yang disebabkan oleh preeklamsi untuk negara berkembang adalah $16,1 \%$, sedangkan di Indonesia sebesar $33 \%$ (WHO 2007).

Penyebab utama terjadinya kematian ibu dapat di bagi 4 (empat) kelompok yaitu, langsung terjadi tanpa dapat diduga sebelumnya, dan tidak diketahui penyebabnya, penyebab langsung kematian ibu yang paling umum di Indonesia adalahpreeklampsi/eklampsia $24 \%$, perdarahan $28 \%$, dan infeksi $11 \%$ (Depkes $\mathrm{RI}, 2007)$.

Berdasarkan penelitian yang dilakukan Manuaba, di Indonesia, pre-eklampsia eklampsia masih merupakan salah satu penyebab kematian ibu, yang berkisar 1,5\% sampai $25 \%$, sedangkan kematian bayi antara 45\% sampai 50\% (Manuaba, 2009). Berbeda dengan penelitian yang dilakukan Betty dan Yanti angka kematian ibu akibat pre-eklampsia di Indonesia cukup tinggi yaitu antara 9,8\% sampai $25 \%$ (Betty dan Yanti, 2011).

Sementara itu berdasarkan data dari Dinas Kesehatan Provinsi Sulawesi Selatan 
jumlah kematian ibu tahun 2015 sebanyak 175 orang dengan penyebab perdarahan sebanyak 91 orang (62\%), preeklampsi 30 orang $(30,7 \%)$, infeksi 7 orang $(5,7 \%)$, dan lain-lain 33 orang $(14,9 \%)$.

Data yang diperoleh dari Medical Record Rumah Sakit Ibu dan Anak Sitti Fatimah Makassar pada tahun 2009 kejadian preeklampsi sebanyak 71 orang dari 205 ibu hamil yang memeriksakan kehamilannya, pada tahun 2011 jumlah kasus preeklampsi sebanyak 120, kemudian pada tahun 2013 tercatat 146 kunjungan ibu hamil dengan kasus preekalmsia 76, pada tahun 2014 jumlah kasus preeklampsi sebanyak 78 kasus, sementara pada tahun 2015 jumlah kasus preeklampsi sebanyak 81 kasus, dan pada tahun 2016 meningkat menjadi 112 kasus preeklamsi.

Studi asupan zat gizi dihubungkan dengan kejadian preeklampsi. Studi kohort pada wanita hamil dengan menggunakan FFQ menemukan maternal dengan pola makan tinggi sayur, makanan nabati, dan minyak sayur telah menurunkan risiko preeklampsi, sementara pola konsumsi tinggi daging olahan, makanan tinggi garam, dan minuman ringan meningkatkan risiko preeklampsi (Nuryani 2012).

Untuk memenuhi target MDG's mengenai penurunan Angka Kematianlbu maka diperlukan kerja keras sehingga perlu adanya antisipasi terhadap faktor risiko yang dapat menyebabkan kejadian pre eklampsia pada ibu.

\section{METODE PENELITIAN}

Jenis penelitian ini adalah Penelitian eksplanatori research, yaitu penelitian yang bertujuan untuk menjelaskan interaksi dua variable atau lebih. Metode penelitian yang diterapkan adalah survai cross sectional. Data dari variabel bebas (Asupan Energi, asupan zat gizi makro dan status gizi) maupun terikat (Kejadian preeklamsi) diambil satu waktu di RSIA Siti Fatimah Kota Makassar.Sampel dalam penelitian ini adalah ibu hamil preeklamsi yang ada di RSIA Siti Fatimah Kota Makassar .

Pengumpulan data dilakukan dengan dua cara yaitu data primer dan data sekunder. Data Primer seperti data yang dikumpulkan dalam proses penelitian melalui wawancara dan pengukuran langsung terhadap sampel yang menjadi objek penelitian yaitu data karasteristik responden, asupan energi dan asupan zat gizi makro serta status gizi, dengan menggunakan kusioner,antropometri dan formulir recall 24 jam. Data skunder seperti Data tentang gambaran lokasi penelitian atau data geografi dicatat dari dokumen pada instansi terkait wilayah penelitian dan data tentang ibu hamil yang preeklamsi diperoleh dari data rekam medis yang tercatat di RSIA Siti Fatimah Kota Makassar.

Pengolahan datai (1) Editing Proses editing dilakukan setelah data terkumpul dan dilakukan dengan memeriksa kelengkapan data, memeriksa kesinambungan data dan keseragaman data, (2)Koding Semua hasil yang diperoleh disederhanakan dengan memberikan symbol tertentu pada setiap kriteria. Pengkodean dilakukan dengan member nama variable dan kode sebelum dipindahkan ke SPSS, (3) Entry Data selanjutanya di-input ke dalam kerja SPSS untuk masing-masing variable. Urutan inputan data berdasarkan nama responden dalam kusioner. Data yang di-input selanjutnya dapat dianalisis menggunakan program SPSS, analisis statistik yang digunakan untuk menguji hipotesis menggunakan uji chisquareuntuk mengujiHubungan Asupan Energi dan Gizi Makro serta Status Gizi pada Pasien Pre-Eklamsi di Rsia Siti Fatimah Kota Makassar. Penyajian data disajikan dalam bentuk tabel distribusi frekuensi beserta dengan penjelasan-penjelasannya

\section{HASIL DAN PEMBAHASAN}

\section{Gambaran Umum Lokasi}

RSKD lbu dan Anak Siti Fatimah adalah rumah sakit milik Pemerintah Daerah Provinsi Sulawasi Selatan. Pada tanggal 4 Februari 2002 berubah dari Rumah Sakit Bersalin Siti Fatimah Menjadi Rumah Sakit lbu Dan Anak Siti Fatimah, sesuai surat keputusan Gubernur Sulawesi Selatan No. 12 tahun 2002. Luas tanah 2.381 M2 dengan luas bangunan 1.808 M2, di Jl Gunung Merapi No. 75 Keluruhan Lajangiru Kecamatan Ujung Pandang Kota Makassar. Ruangan dan tempat tidur di RSIA Siti Fatimah sebagai berikut tempat tidur pemeriksaan : poli anak 1 tempat tidur, poli gigi 1 tempat tidur, poli umum 1 tempat tidur, poli kandungan dan KB 1 tempat tidur, ANC 1 tempat tidur, kamar bersalin 8 tempat tidur, kamar operasi 2 tempat tidur, ruang pemulihan 5 tempat tidur, radiologi 1 tempat tidur, fisioterapi 1 tempat tidur, UGD 5 tempat tidur. 


\section{Kararkteristik Sampel}

Tabel 01

Distribusi Responden Berdasarkan Umur di RSKD Ibu dan Anak Siti Fatimah Kota Makassar 2017

\begin{tabular}{ccc}
\hline Umur & Jumlah & $\%$ \\
\hline$<20$ tahun & 2 & 5,9 \\
$20-35$ tahun & 21 & 61,6 \\
$>35$ tahun & 11 & 32,5 \\
\hline Total & 34 & 100
\end{tabular}

Sumber : Data Primer

Berdasarkan tabel diatas diketahui bahwa kelompok umur pasien preklamsi di RSKD Ibu dan Anak Siti Fatimah Kota
Makassar yang terbanyak adalah kelompok umur $20-35$ tahun yaitu 21 orang ( $61.6 \%)$.

Tabel 02

Distribusi Responden Berdasarkan Tingkat Pendidikan di RSKD Ibu dan Anak Siti Fatimah Kota Makassar 2017

\begin{tabular}{ccc}
\hline Jenis Pendidikan & Jumlah & $\%$ \\
\hline Tidak Tamat SD & 1 & 2,9 \\
Tamat SD & 9 & 26,5 \\
SMP/MTS Sederajat & 12 & 35,3 \\
SMA/ma Sederajat & 11 & 32,4 \\
Diploma & 1 & 2,9 \\
\hline Total & 34 & 100
\end{tabular}

Sumber : Data Primer

Berdasarkan tabel diatas diketahui

Makassar yang terbanyak adalah SMP atau bahwa tingkat pendidikan pasien preklamsi di sederajat yaitu 12 orang ( $35,3 \%)$.

RSKD Ibu dan Anak Siti Fatimah Kota Tabel 03

Distribusi Responden Berdasarkan Jenis Pekerjaan di RSKD Ibu dan Anak Siti Fatimah Kota Makassar 2017

\begin{tabular}{ccc}
\hline Jenis Pekerjaan & Jumlah & $\%$ \\
\hline IRT & 34 & 100 \\
\hline Total & 34 & 100
\end{tabular}

Sumber : Data Primer

Berdasarkan tabel diatas diketahui bahwa pekerjaan pasien preklamsi di RSKD adalah semua IRT sebanyak 34 orang ( $100 \%$ Ibu dan Anak Siti Fatimah Kota Makassar ) .

Tabel 04

Distribusi Responden Berdasarkan Usia Kehamilan Ibu di RSKD Ibu dan Anak Siti Fatimah Kota Makassar 2017

\begin{tabular}{ccc}
\hline Usia Kehamilan & Jumlah & $\%$ \\
\hline Trimester 2 & 3 & 8,8 \\
Trimester 3 & 31 & 91,2 \\
\hline Total & 34 & 100
\end{tabular}

Sumber : Data Primer 
Berdasarkan tabel diatas diketahui bahwa kelompok usia kehamilan pasien preklamsi di RSKD Ibu dan Anak Siti Fatimah
Kota Makassar yang terbanyak adalah kelompok umur kehamilan pada trimester 3 yaitu 31 orang $(91,2 \%)$.

\section{Variabel Penelitian}

Tabel 05

Distribusi Responden di RSKD Ibu dan Anak Siti Fatimah Kota Makassar 2017

\begin{tabular}{ccc}
\hline Preeklamsia & Jumlah & $\%$ \\
\hline Ringan & 28 & 82,4 \\
Berat & 6 & 17,6 \\
\hline Total & 34 & 100
\end{tabular}

Sumber : Data Primer

Berdasarkan hasil penelitian ini diketahui bahwa data preaeklamsia ringan

sebanyak 28 orang $(82,4 \%)$ dan preeklamsia berat sebanyak 6 orang $(17,6 \%)$.

Tabel 06

Distribusi Responden Berdasarkan Asupan Energi di RSKD Ibu dan Anak Siti Fatimah Kota Makassar 2017

\begin{tabular}{ccc}
\hline Asupan Energi & Jumlah & $\%$ \\
\hline Baik & 13 & 38,3 \\
Kurang & 21 & 61,7 \\
\hline Total & 34 & 100
\end{tabular}

Sumber : Data Primer

Berdasarkan hasil penelitian ini diketahui bahwa asupan energi pasien

Kota Makassar pada umumnya kurang preeklamsi di RSKD Ibu dan Anak Siti Fatimah

Tabel 07

Distribusi Responden Berdasarkan Asupan Zat Gizi Makro di RSKD Ibu dan Anak Siti Fatimah Kota Makassar 2017

\begin{tabular}{lcc}
\hline \multicolumn{1}{c}{ Asupan } & $\mathrm{n}=34$ & $\%$ \\
\hline Protein & & \\
$\quad$ Baik & 12 & 35,3 \\
$\quad$ Kurang & 22 & 64,7 \\
Lemak & & \\
$\quad$ Baik & 16 & 47 \\
$\quad$ Kurang & 18 & 53 \\
Karbohidrat & & \\
$\quad$ Baik & 10 & 29,4 \\
$\quad$ Kurang & 24 & 70,6 \\
\hline
\end{tabular}

Sumber : Data Primer

Berdasarkan hasil penelitian ini diketahui bahwa asupan zat gizi makro pasien preeklamsi di RSKD Ibu dan Anak Siti Fatimah Kota Makassar pada umumnya kurang, meliputi protein sebanyak 22 orang $(64,7 \%)$, Lemak sebanyak 18 orang $(53 \%)$, serta Karbohidrat sebanyak 24 orang $(70,6 \%)$. 
Tabel 08

Distribusi Responden Berdasarkan LILA di RSKD Ibu dan Anak Siti Fatimah Kota Makassar 2017

\begin{tabular}{ccc}
\hline Status Gizi & Jumlah & $\%$ \\
\hline Normal & 31 & 91,2 \\
Kurang & 3 & 8,8 \\
\hline Total & 34 & 100
\end{tabular}

Sumber : Data Primer

Berdasarkan hasil penelitian ini diketahui bahwa status gizi pasien preeklamsi di RSKD lbu dan Anak Siti Fatimah Kota Makassar pada umumnya baik sebanyak 31 orang $(91,2 \%)$.

\section{Hubungan Antar Variabel}

Berdasarkan hasil penelitian ini diketahui bahwa tidak ada hubungan antara asupan energi pada pasien preeklamsi di RSKD lbu dan Anak Siti Fatimah Kota Makassar $(p=0,584)$.

Tabel 09

Distribusi Responden Berdasarkan Hubungan Asupan Energi pada Pasien Preeklamsi Di RSKD Ibu dan Anak Siti Fatimah Kota Makassar 2017

\begin{tabular}{cccccccc}
\hline \multirow{2}{*}{$\begin{array}{c}\text { Asupan } \\
\text { Energi }\end{array}$} & \multicolumn{4}{c}{ Preeklamsi } & \multicolumn{2}{c}{ Jumlah } & \multirow{2}{*}{$\mathrm{p}$ Value } \\
\cline { 2 - 6 } & \multicolumn{2}{c}{ Ringan } & \multicolumn{2}{c}{ Berat } & & \\
\cline { 2 - 7 } & $\mathrm{n}$ & $\%$ & $\mathrm{n}$ & $\%$ & $\mathrm{n}$ & $\%$ & \\
\hline Baik & 11 & 39,2 & 2 & 33,3 & 13 & 38,2 & \\
Kurang & 17 & 60,8 & 4 & 66,7 & 21 & 61,8 & 0,584 \\
\hline Jumlah & 28 & 100 & 6 & 100 & 34 & 100 & \\
\hline
\end{tabular}

Sumber : Data Primer

Hasil penelitian ini tidak sejalan dengan penelitian yang dilakukan oleh Nuryani pada tahun 2013 yang menunjukkan hasil bahwa persentase asupan energi kurang pada kelompok kasus dengan nilai $p=0,001$.

Secara teoritis diketahui bahwa asupan energi pada individu adalah pembatas terhadap pemenuhan kebutuhan gizi yang lain. Artinya jika asupan energi terpenuhi maka semua zat gizi makro lainnya biasanya akan juga terpenuhi ( Almatsier, 2004).

Berdasarkan hasil penelitian ini diketahui bahwa tidak ada hubungan antara asupan zat gizi makro pada pasien preeklamsi di RSKD lbu dan Anak Siti Fatimah Kota Makassar, masing-masing protein $(p=0,611)$, lemak $(p=0,416)$, dan karbohidrat $(p=0,649)$.

Tabel 10

Distribusi Responden Berdasarkan Hubungan Asupan Zat Gizi Makro Pada Pasien Preeklamsi Di RSKD Ibu dan Anak Siti Fatimah Kota Makassar 2017

\begin{tabular}{|c|c|c|c|c|c|c|c|}
\hline \multirow{2}{*}{$\begin{array}{c}\text { Asupan zat gizi } \\
\text { makro }\end{array}$} & \multicolumn{2}{|c|}{ Ringan } & \multicolumn{2}{|c|}{ Berat } & \multirow{2}{*}{$n=34$} & \multirow[b]{2}{*}{$\%$} & \multirow{2}{*}{$p$ Value } \\
\hline & $n=28$ & $\%$ & $\mathrm{n}=6$ & $\%$ & & & \\
\hline \multicolumn{8}{|l|}{ Protein } \\
\hline Baik & 13 & 46,4 & 3 & 50 & 16 & 47 & \multirow[t]{2}{*}{0,611} \\
\hline Kurang & 15 & 53,6 & 3 & 50 & 18 & 53 & \\
\hline \multicolumn{8}{|l|}{ Lemak } \\
\hline Baik & 9 & 32,1 & 1 & 16,6 & 10 & 29,4 & \multirow[t]{2}{*}{0,416} \\
\hline Kurang & 19 & 67,9 & 5 & 83,4 & 24 & 70,6 & \\
\hline \multicolumn{8}{|l|}{ Karbohidrat } \\
\hline Baik & 10 & 35,7 & 2 & 33,3 & 12 & 35,2 & \multirow[t]{2}{*}{0,649} \\
\hline Kurang & 18 & 64,3 & 4 & 66,7 & 22 & 64,8 & \\
\hline
\end{tabular}

Sumber : Data Primer 
Penelitian ini sejalan dengan penelitian yang dilakukan oleh Siti Widyaningrum pada tahun 2012 dengan menunjukkan hasil didapatkan nilai $P=0,599$, artinya tingkat konsumsi zat gizi makro terbukti tidak memiliki hubungan pada pasien preeklamsi.
Berdasarkan hasil penelitian ini diketahui bahwa tidak ada hubungan antara status gizi pada pasien preeklamsi di RSKD Ibu dan Anak Siti Fatimah Kota Makassar ( $p=$ $0,547)$.

Tabel 11

Distribusi Responden Berdasarkan Hubungan Status Gizi Pada Pasien Preeklamsi Di RSKD Ibu dan Anak Siti Fatimah Kota Makassar 2017

\begin{tabular}{cccccccc}
\hline \multirow{2}{*}{$\begin{array}{c}\text { Status } \\
\text { gizi }\end{array}$} & \multicolumn{4}{c}{ Preeklamsi } & \multirow{2}{*}{ Jumlah } & \multirow{2}{*}{ p Value } \\
\cline { 2 - 6 } & \multicolumn{2}{c}{ Ringan } & \multicolumn{2}{c}{ Berat } & & \\
\cline { 2 - 7 } & $\mathrm{n}$ & $\%$ & $\mathrm{n}$ & $\%$ & $\mathrm{n}$ & $\%$ & \\
\hline Normal & 25 & 89 & 6 & 100 & 31 & 91 & \\
Kurang & 3 & 11 & 0 & 0 & 3 & 9 & 0,547 \\
\hline Jumlah & 28 & 100 & 6 & 100 & 34 & 100 & \\
\hline
\end{tabular}

Sumber : Data Primer

Penelitian ini sejalan dengan penelitian yang dilakukan oleh Muhammad Nur Anas pada tahun 2013 dengan menunjukkan hasil didapatkan nilai $p=0,85$, artinya bahwa ibu hamil preeklamsi yang ukuran LILA >23,5 bukan menjadi faktor risiko utama pada kejadian preeklampsia.

\section{KESIMPULAN}

1. Rata-rata asupan energi ibu preeklamsi yang memiliki asupan baik hanya 13 $(38,3 \%)$, dan kurang $21(61,7 \%)$.

2. Rata-rata asupan protein ibu preeklmasi yang memiliki asupan protein baik hanya 12 (35,3\%), dan kurang 22 (64,7\%), asupan lemak yang memiliki asupan yang baik $16(47,0 \%)$, dan kurang $18(53,0 \%)$, kemudian asupan karbohidrat yang baik 10 $(29,4 \%)$, dan kurang $24(70,6 \%)$.

3. Status gizi ibu preeklamsi yang memiliki status gizi normal $31(91,2 \%)$, dan kurang 3 ( $8,8 \%)$.

4. Tidak ada hubungan antara asupan energi pada pasien preeklamsi ( $p=0,584$ )

5. Tidak ada hubungan asupan protein dengan kejadian preeklamsi $(p=0,611)$, dan tidak ada hubungan asupan lemak dengan kejadian preeklamsi $(p=0,416)$, serta tidak ada hubungan asupan karbohidrat pada pasien preeklamsi $(p=$ 0,649 ).

6. Tidak ada hubungan antara status gizi pada pasien preeklamsi $(p=0,547)$.

\section{SARAN}

1. Disarankan kepada ibu hamil agar selalu menjaga kehamilan dengan cara menjaga status gizi, memperbaiki pola makan dengan mengikuti diet dari rumah sakit, mengonsumsi makanan yang bergizi, istirahat yang cukup dan olah raga.

2. Bagi peneliti lain, hendaknya melakukan penelitian dengan desain studi dengan jumlah sampel yang lebih besar dan melakukan penelitian lanjutan terkait kejadian preeklamsi menggunakan faktorfaktor lain yang belum ditiliti seperti zat gizi mikro serta kehamilan ganda/kembar dan sebagainya.

\section{DAFTAR PUSTAKA}

Almatsier, Sunita. 2006. Prinsip dasar ilmu gizi. Jakarta; Gramedia Pustaka Utama.

Almatsier S, 2004, Penuntun Diit edisi baru. Instalasi Gizi Perjan RS Dr Cipto Mangunkusumo dan Asosiasi Dietesien Indonesia. Gramedia Pustaka Utama, Jakarta.

Ariyani. 2012. "validitas lingkar lengan atas mendeteksi risiko kekurangan energi kronis pada wanita Indonesia " jurnal kesehatan masyarakat nasional.

Arisman. 2004. Gizi dalam daur kehidupan. jakarta;EGC.

Astuti, 2011.Buku Pintar Kehamilan.Jakarta : EGC

Andi Besse Rawasiah. 2012. Hubungan Faktor Konsumsi Makanan Dengan Kejadian Preeklamsia Pada Ibu Hamil Di Puskesmas Pattingalloang. Universitas Hasanuddin.

Baliwati, yayuk.2009. Pengantar Pangan dan Gizi .Jakarta; penebar swadaya.

Betty, F \&Yanti.2011.Hubungan Karakteristik Ibu dengan Kejadian Pre-eklamsia di RSUI Yakssi Sragen. Jurnal 
Kebidanan, Vol.III, No.1,. Akademi Kebidanan Estu Utomo Boyolali

Beck, Mary E. 2011.IImu Gizi dan Diet.Penerbit Andi dan Penerbit Yayasan.

Childinfo, 2012.A Global Overview of Maternal Mortality.Diakses tanggal 16 agustus 2016.http://www.childinfo.org/mater nal mortality.html.

Chapman, 2006.Asuhan Kebidanan Persalinan dan Kelahiran.EGC : Jakarta

Dinkes Sulsel. 2015. Profil Kesehatan Sulawesi Selatan. Makassar: Dinas Kesehatan.

Departemen kesehatan RI. 2007. pedoman pengukuran dan pemeriksaan ,Jakarta; departemen kesehatan RI.

Hidayati, Farida. 2011. Hubungan antara pola konsumsi, penyakit infeksi dan pantang makanan terhadap risiko kurang energy kronis (KEK) pada ibu hamil puskesmas ciputat kota tangerang selatan. skripsiuniversitas islam negri syarif hidayatullah.Jakarta.

Kartasapoetra \& Marsetyo. 2006. IImu Gizi Korelasi, Kesehatan dan Produktivitas Kerja. Jakarta : Penerbit Rineka Cipat.

Lisnawati. 2012. Kejadian Preeklampsi Berat Pada Ibu Hamil Dan Bersalin Studi Kasus Terhadap Pasien Di Rumah Sakit Umum Daerah Dr. Pirngadi. Medan.

Manuaba, 2010.llmu Kebidanan Penyakit Kandungan dan Keluarga Berencana Untuk Pendidikan Bidan, EGC : Jakarta.

Manuaba.I.A.C. 2009.Memahami Kesehatan Reproduksi Wanita.Jakarta: EGC.

Nuryani. 2012. Hubungan Pola Makan,Sosial Ekonomi,Antenatal Care dan Karasteristik Ibu Hamil Dengan Kasus Preeklamsia di Kota Makassar.

Muhammad Nur Anas. 2013. Hubungan Lingkar Lengan Atas (Lila) Pada lbu Hamil Dengan Angka Kejadian Preeklampsia Di Rs. Pku Muhammadiyah Surakarta.Thesis. Uni versitas Muhammadiyah

Surakarta.

Rohfiin, 2016 .Mini KTI Tren Persalinan (online) http://www.academia.edu diakses 04 April 2016.

Riskesdas. 2013. Jakarta: Badan Penelitian dan Pengembangan Kesehatan Kementerian Kesehatan, Republik Indonesia.

Rozikhan. 2013. Faktor-faktor risiko Terjadinya Pre-eklamsia Berat Di Rumah Sakit Dr.H.Soewondo Kendal.Thesis.Universitas Diponegoro.Semarang.

Rukiyah, 2010. Asuhan Kebidanan IV (Patologi Kebidanan). Jakarta: Trans Info Media.

Simkin,2008. Panduan Lengkap Kehamilan, Melahirkan, dan Bayi, Edisi Revisi. Jakarta: Arcan.

Soeditama, Achmad Djaeni , 2009. IImu Gizi untuk mahasiswa dan profesi jilid II.Jakarta;Dian rakyat..

Supariasa.2001. Penilaian Status Gizi. Jakarta: Buku Kedokteran EGC.

Syafiq, Ahmad. 2010. Gizi dan Kesehatan Masyarakat. Jakarta: Pt. Raja Grafindo Persada.

Sinclair, 2012. Buku Saku Kebidanan. Jakarta : EGC.

Siti Widyaningrum. 2012. Hubungan Antara Konsumsi Makanan Dengan Kejadian Preeklamsia Pada lbu Hamil. Universitas Jember.

WHO. 2007. Maternal Mortality in 2005. http:// www.who.int/whosis/mme_2005.pdf. (13 agustus 2016).

Wylie L., 2010. Manajemen Kebidanan Gangguan Medis Kehamilan dan Persalinan. Jakarta: EGC.

WNPG X, 2012. Penyempurnaan kecukupan zat gizi Indonesia. Jakarta.

Winkjosastro. 2010. IImu Kebidanan. Jakarta: Yayasan BinaPustaka SarwonoPrawirohardjo.

Yustiana, I. 2007. upaya Strategis Menurunkan $A K I$ dan $A K B$, Jurnal 